\title{
SEGMENTASI WARNA CITRA DENGAN DETEKSI WARNA HSV UNTUK MENDETEKSI OBJEK
}

\author{
Benedictus Yoga Budi Putranto, Widi Hapsari, Katon Wijana \\ Fakultas Teknik Program Studi Teknik Informatika \\ Universitas Kristen Duta Wacana Yogyakarta \\ Email: yoga.benedict@gmail.com, widi@ukdw.ac.id,katon@ukdw.ac.id
}

\begin{abstract}
Abstrak :
Deteksi objek pada suatu citra 2 dimensi merupakan suatu proses yang cukup kompleks untuk dilakukan oleh karena itu diperlukan suatu pendekatan visi komputer (computer vision) sehingga bagian objek yang diinginkan dapat dikenali komputer dengan akurat. Penelitian ini akan memaparkan penerapan metode segmentasi warna dengan deteksi warna HSV oleh Giannakopoulos untuk menghasilkan objek segmen citra berupa blob sehingga dapat terdeteksi komputer. Berdasarkan hasil pengujian dan analisa diperoleh kesimpulan bahwa kontrol pengguna dalam hal penentuan sampel warna dan toleransi warna berperan penting dalam proses segmentasi; sampel warna akan menghasilkan nilai acuan warna sebagai acuan segmentasi dan toleransi warna digunakan sebagai jangkauan filter dalam proses segmentasi. Proses deteksi objek akan mengolah segmen warna yang dihasilkan oleh proses segmentasi sehingga dapat diketahui banyaknya objek terdeteksi, luas area dan titik pusat tiap objek.
\end{abstract}

Kata Kunci : computer vision, segmentasi warna, deteksi warna, giannakoupolos

\section{Pendahuluan}

Perkembangan sistem computer vision atau visi komputer saat ini telah banyak dimanfaatkan dalam membantu manusia dalam proses pengenalan atau deteksi objek. Proses pengenalan suatu objek merupakan pekerjaan yang cukup sulit sehingga dalam proses tersebut disarankan untuk mengimplementasikan teknologi computer vision guna mengambil peranan untuk mengenali objek dalam suatu citra 2 dimensi.

Dalam proses pengenalan objek atau deteksi objek diperlukan suatu pemisahan bagian atau segmen tertentu dalam citra yang akurat, proses pemisahan tersebut dikenal sebagai proses segmentasi. Proses pengenalan segmen merupakan salah satu kunci dalam mendapatkan suatu hasil pengenalan atau deteksi yang akurat. Segmentasi membagi suatu 
citra menjadi bagian-bagian atau segmen yang lebih sederhana dan bermakna sehingga dapat dilakukan analisis lebih lanjut. Kegunaan segmentasi menurut Forsyth dan Ponce (2003) adalah pengambilan informasi dari citra seperti pencarian bagian mesin, pencarian manusia dan pencarian citra yang serupa. Secara umum pendekatan segmentasi citra yang sering digunakan adalah melalui pendekatan intensitas, pendekatan warna dan pendekatan bentuk (Rujikietgumjorn, 2008).

Segmentasi warna merupakan pemisahan segmen dalam suatu citra berdasarkan warna yang terkandung dalam citra. Dalam perkembangan sistem computer vision telah dilakukan berbagai macam metode untuk melakukan segmentasi warna seperti metode clustering dan metode indeks. Pada penelitian ini penulis akan mencoba untuk melakukan segmentasi warna dengan metode deteksi warna HSV. Ruang lingkup warna HSV terdiri dari 3 elemen yaitu Hue mewakili warna, Saturation mewakili tingkat dominasi warna, dan Value mewakili tingkat kecerahan. Dengan demikian metode ini cenderung mendeteksi warna dan tingkat dominasi serta kecerahannya

\section{Segmentasi Citra}

Segmentasi citra akan membagi-bagi suatu citra menjadi daerah-daerah atau obyekobyek yang dimilikinya. Menurut Castleman (1996) segmentasi citra merupakan suatu proses memecah suatu citra digital menjadi banyak segmen/bagian daerah yang tidak saling bertabrakan (nonoverlapping). Dalam konteks citra digital daerah hasil segmentasi tersebut merupakan kelompok piksel yang bertetangga atau berhubungan.

Segmentasi citra dapat dilakukan melalui beberapa pendekatan, menurut Castleman (1996) terdapat 3 macam pendekatan, antara lain:

- Pendekatan batas (boundary approach), pendekatan ini dilakukan untuk mendapatkan batas yang ada antar daerah.

- Pendekatan tepi (edge approach), pendekatan tepi dilakukan untuk mengidentifikasi piksel tepi dan menghubungkan piksel-piksel tersebut menjadi suatu batas yang diinginkan

- Pendekatan daerah (region approach), pendekatan daerah bertujuan untuk membagi citra dalam daerah-daerah sehingga didapatkan suatu daerah sesuai kriteria yang diinginkan.

Proses segmentasi digunakan dalam berbagai penerapan, meskipun metode yang digunakan sangat bervariasi, semuanya memiliki tujuan sama: mendapatkan representasi sederhana yang berguna dari suatu citra. Terdapat berbagai macam metode dalam melakukan segmentasi, cukup sulit untuk menentukan metode yang komprehensif, oleh karena itu pemilihan metode bergantung pada pendekatan yang akan digunakan dan fitur yang ingin diperoleh dari citra 


\section{Segmentasi Warna Dengan Deteksi Warna HSV}

Segmentasi warna merupakan proses segmentasi dengan pendekatan daerah yang bekerja dengan menganalisis nilai warna dari tiap piksel pada citra dan membagi citra tersebut sesuai dengan fitur yang diinginkan. Segmentasi citra dengan deteksi warna HSV menurut Gunanto (2009) menggunakan dasar seleksi warna pada model warna HSV dengan nilai toleransi tertentu.

Pada metode segmentasi dengan deteksi warna HSV menurut Giannakupoulos (2008), dilakukan pemilihan sampel piksel sebagai acuan warna untuk membentuk segmen yang diinginkan. Citra digital menggunakan model warna $R G B$ sebagai standar acuan warna, oleh karena itu proses awal pada metode ini memerlukan konversi model warna RGB ke HSV. Untuk membentuk segmen sesuai dengan warna yang diinginkan maka ditentukan nilai toleransi pada setiap dimensi warna HSV, kemudian nilai toleransi tersebut digunakan dalam perhitungan proses adaptive threshold. Hasil dari proses threshold tersebut akan membentuk segmen area dengan warna sesuai toleransi yang diinginkan. Secara garis besar, gambaran proses segmetnasi dapat dilihat pada Gambar 1 dan berikut ini merupakan proses segmentasi menurut Giannakupoulos (2008).

- Tentukan citra RGB yang menjadi obyek deteksi, nilai warna HSV yang menjadi acuan (hasil proses pelatihan data) dan nilai toleransi HSV yang digunakan.

- Transpose citra RGB ke HSV

- Lakukan filter warna pada citra berdasarkan nilai acuan ( $T$ ) dan nilai toleransi (tol). Dengan $x$ sebagai warna HSV pada piksel yang ada maka warna yang tidak termasuk dalam rentang $T$-tol $<x<T+$ tol diberi warna hitam.

- Transpose kembali citra ke $R G B$, tampilkan hasil filter. 


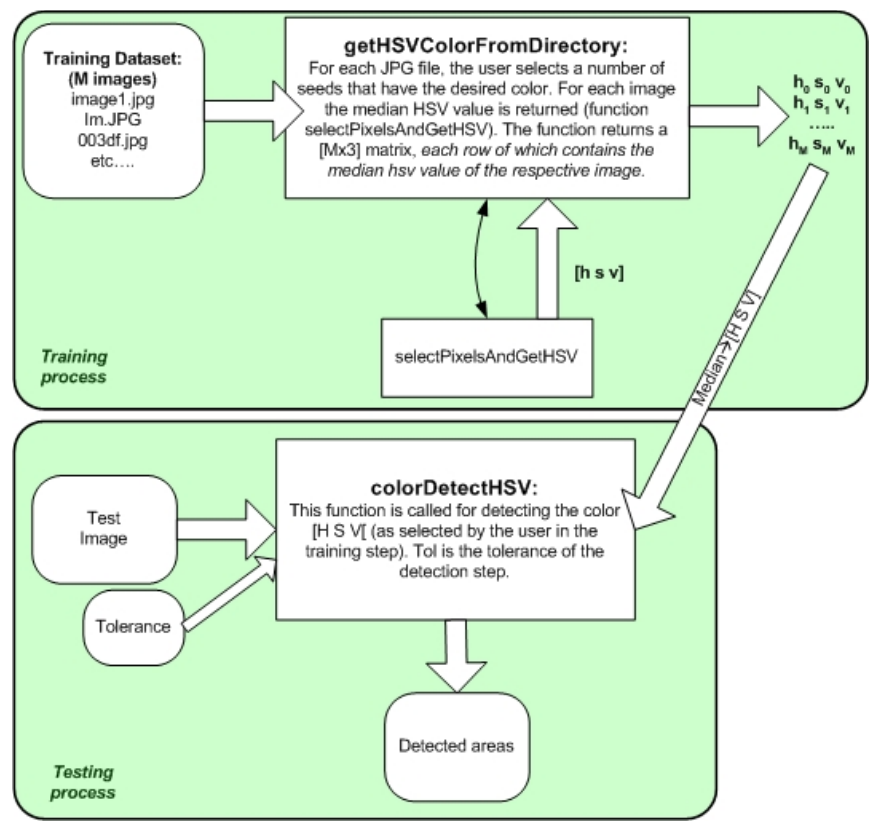

Gambar 1. Skema Deteksi Warna HSV

Gunanto (2009) mencoba melakukan segmentasi dengan menggunakan metode deteksi warna HSV pada bagian tubuh manusia yang diberi warna tertentu. Gunanto melakukan penelitian berdasarkan metode deteksi warna HSV Giannakupoulos untuk memisahkan bagian tubuh manusia yang diberi warna tertentu. Penelitian tersebut menggunakan data input berupa citra 2 dimensi dengan latar belakang homogen berwarna putih dan fitur model manusia. Model manusia mengenakan pakaian dengan warna tertentu pada tiap bagian tubuh manusia yang akan dikenali. Proses segmentasi warna dengan menggunakan deteksi warna HSV menghasilkan segmen warna yang akurat sesuai dengan warna sampel dan nilai toleransi yang diberikan. Hasil segmentasi warna tersebut menghasilkan segmen citra yang membentuk suatu blob, yaitu sekumpulan piksel bertetangga yang memiliki nilai tertentu.

\section{Pemetaan dan Perhitungan Objek}

Blob merupakan sekumpulan piksel-piksel yang memiliki hubungan tetangga. Proses perhitungan blob dapat dilakukan dengan melakukan analisis piksel yang bertetangga. Piksel bertetangga pada sebuah piksel ditentukan sebagai piksel yang berjarak 1 dari piksel asal. Proses perhitungan blob akan memanfaatkan relasi piksel 8-neighbors. Gambar 2 di bawah ini merupakan gambaran sederhana dari relasi 8-neighbors. 


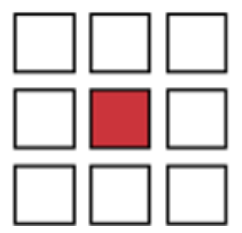

Gambar Error! No text of specified style in document.. Relasi piksel 8-neighbors

Pada gambar 2 piksel asal merupakan piksel berwarna coklat dan piksel putih merupakan piksel tetangga dari piskel asal. Pada relasi 4-neighbors piksel diagonal tidak dianggap sebagai piksel tetangga, sedangkan pada relasi 8-neighbors piksel diagonal akan dianggap sebagai piksel tetangga sehingga akan memberikan hasil pemetaan yang lebih akurat dibandingkan relasi 4-neighbors.

Perhitungan blob berdasarkan pustaka pengolahan citra AForge.Net terdiri dari beberapa proses yaitu: pemetaan objek, pengumpulan informasi objek, serta filter objek berdasarkan ukuran. Proses pemetaaan objek akan menelusuri dan melabeli setiap piksel pada citra sehingga dapat diketahui piksel pembentuk blob pada citra. Proses pengumpulan informasi akan mengolah label tiap piksel sehingga diketahui luas area, tingkat kepenuhan dan titik pusat blob. Proses filter objek akan menyeleksi blob yang akan diproses berdasarkan tinggi dan lebarnya. Menurut pustaka AForge.Net langkah-langkah perhitungan blob adalah sebagai berikut.

1. Proses pemetaan objek akan menelusuri tiap piksel pada setiap baris yang ada dan memberikan label pada piksel yang yang memiliki nilai warna selain hitam (RGB = $0 \quad 0$ 0). Setiap piksel yang memiliki relasi hubungan 8-neighbors akan diberikan label yang sama.

2. Proses pengumpulan informasi blob, akan mengumpulkan dan mengolah informasi tiap piksel yang bertetangga berdasarkan letak dan label yang dihasilkan oleh proses pemetaan objek. Letak dan label piksel yang bertetangga tersebut digunakan untuk membentuk suatu blob dan informasi pendukungnya seperti luas area, tingkat kepenuhan, titik pusat dan area kotak blob.

Proses filter blob, akan melakukan filter berdasarkan tinggi dan lebar blob. Blob dengan tinggi atau lebar di bawah nilai minimum akan dihilangkan dari peta objek. Setelah blob dengan dimensi yang tidak sesuai syarat minimum dihilangkan, dilakukan update label blob terdeteksi.

\section{Analisa Toleransi Terhadap Hasil Segmentasi Warna}

Salah satu faktor yang mempengaruhi hasil segmentasi citra adalah toleransi warna. Toleransi warna terdiri dari 3 unsur yaitu toleransi hue, saturation, dan value. Tiap unsur toleransi akan memberikan hasil segmentasi citra yang berbeda-beda. Nilai toleransi akan menentukan rentang filter pada proses segmentasi warna; ditentukan nilai acuan warna $X$ dengan toleransi $T$ maka pada proses segmentasi akan dilakukan filter warna pada rentang $X-T$ 
sampai dengan $\mathrm{X}+\mathrm{T}$. Berikut ini merupakan beberapa contoh kasus yang akan menunjukan pengaruh toleransi terhadap hasil segmentasi.

Hue merupakan salah satu elemen dalam ruang warna HSV yang mewakili nilai warna sehingga nilai toleransi hue juga akan mempengaruhi nilai warna yang terseleksi dalam proses segmentasi. Nilai hue direpresentasikan dalam bentuk lingkaran dan memiliki rentang berupa sudut antara $0^{\circ}-360^{\circ}$, penggambaran elemen warna hue dapat dilihat pada Gambar 3 di bawah ini.

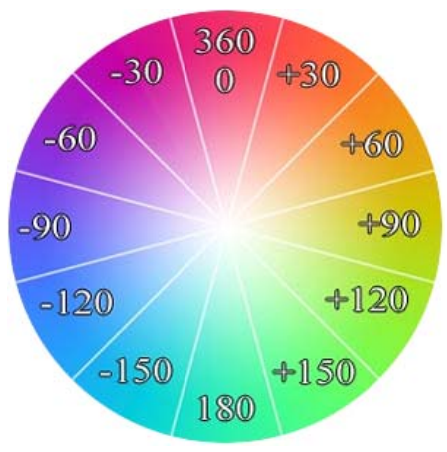

Gambar 3. Lingkaran Elemen Warna Hue

Oleh karena elemen warna hue berupa lingkaran dan dituliskan dalam sudut maka setiap operasi yang berkaitan dengan elemen warna hue (penambahan/ pengurangan, perhitungan toleransi, filter warna) merupakan operasi sudut. Penambahan nilai hue sebesar $\mathrm{n}$ akan terjadi pergeseran sudut sebesar $n^{0}$ searah jarum jam sedangkan untuk pengurangan sebesar $n$ akan terjadi pergeserah sudut sebesar $n^{\circ}$ berlawanan dengan arah jarum jam. Sifatsifat nonlinear tersebut juga akan berlaku pada jangkauan filter pada elemen warna hue sehingga untuk nilai acuan sebesar $X$, toleransi sebesar $T$, dan jangkauan filter awal $(X-T)$ sampai dengan akhir $(X+T)$, nilai awal dapat lebih besar dari nilai akhir $(X-T>X+T)$. Kasus berikut ini merupakan contoh kasus penggunaan toleransi hue pada proses segmentasi, sebuah gambar beberapa lingkaran dengan nilai hue yang berbeda-beda akan tetapi memiliki nilai saturation dan value yang sama.

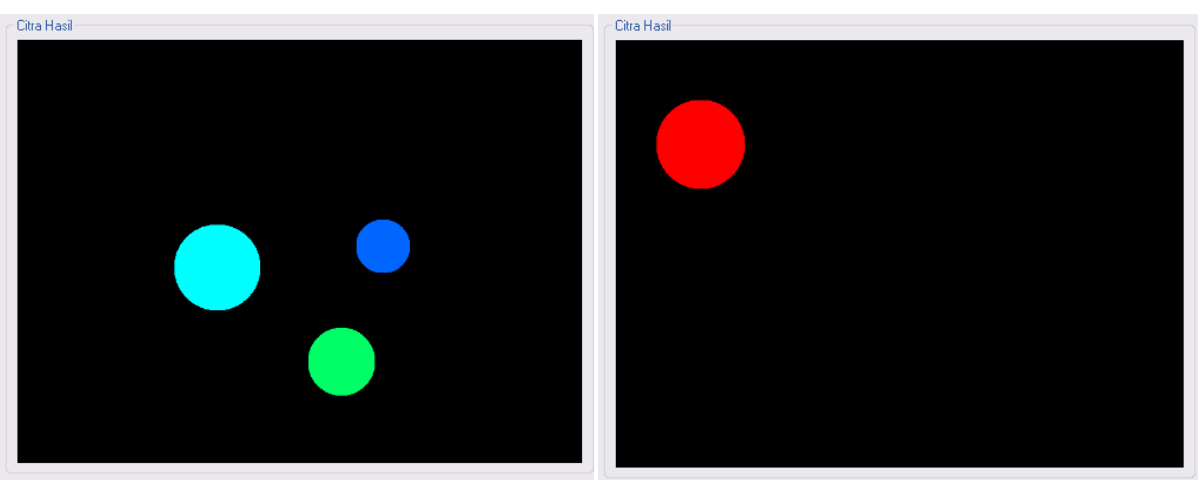

Gambar 4. Segmentasi Dengan Toleransi Hue 
Saturation merupakan salah satu elemen warna HSV yang mewakili tingkat intensitas warna. Pada nilai tingkat kecerahan (value) yang sama nilai saturation akan menggambarkan kedekatan suatu warna pada warna abu-abu. Pada sistem nilai saturasi memiliki rentang antara 0 (minimum) dan 1 atau 100\% (maksimum). Berikut ini merupakan contoh kasus pengaruh nilai toleransi saturation pada proses segmentasi. Pada kasus ini akan menggunakan sebuah citra dengan beberapa objek lingkaran yang memiliki tingkat saturation berbeda tapi memiliki nilai hue dan value sama. Berdasarkan contoh kasus tersebut dapat dilihat bahwa nilai toleransi saturation mempengaruhi tingkat kemurnian warna yang ikut terseleksi dalam proses segmentasi.

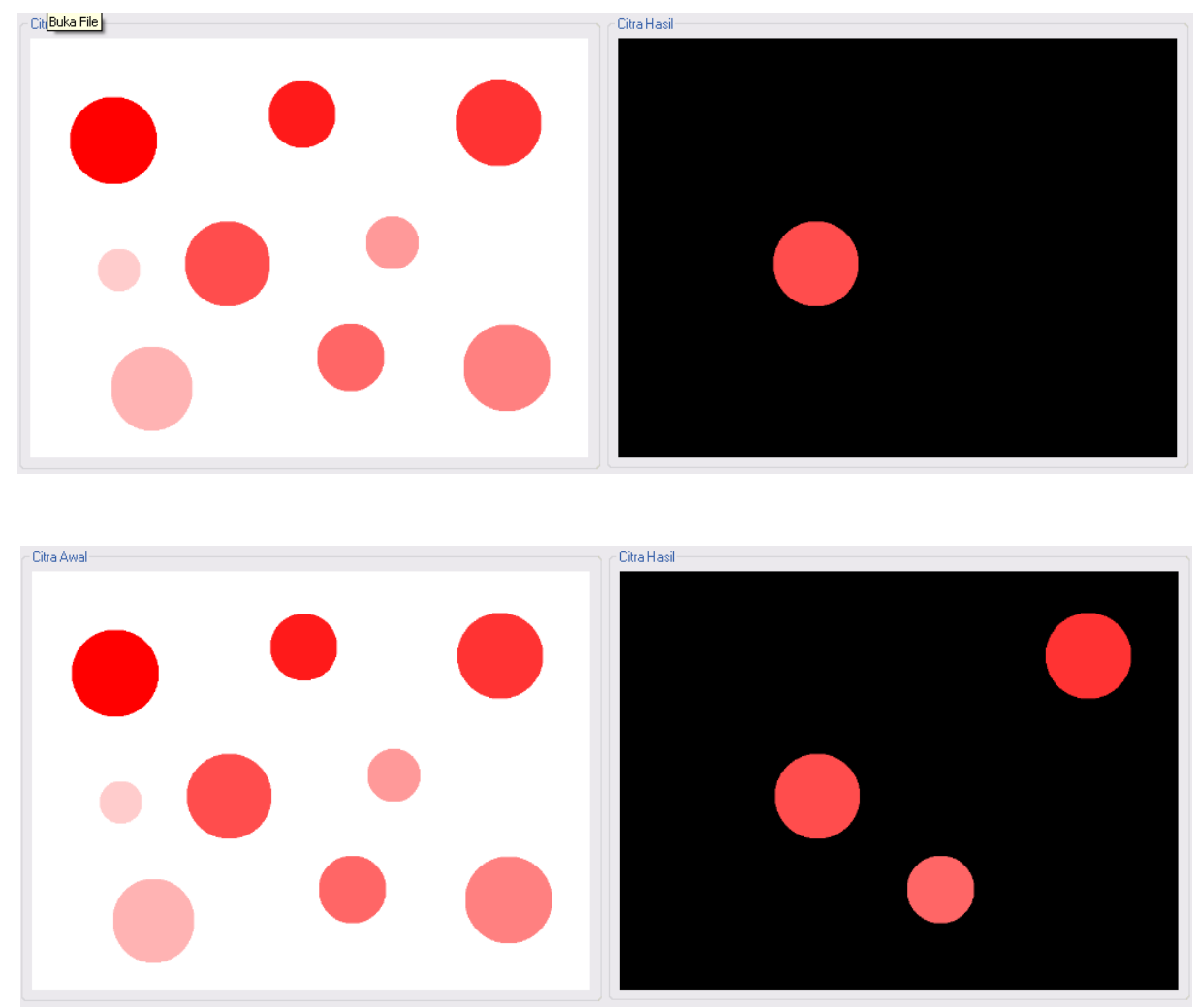

Gambar 5a (atas) dan 5b (bawah). Segmentasi Dengan Toleransi Saturation

Dalam ruang warna HSV, untuk merepresentasikan tingkat kecerahan warna digunakan elemen value. Pada nilai value maksimum warna yang dihasilkan adalah warna dengan tingkat kecerahan maksimum sedangkan pada value minimum dihasilkan warna dengan tingkat kecerahan minimum (warna hitam). Berapapun nilai hue dan saturation warna, jika nilai value yang dimiliki adalah 0 (minimum) maka warna yang dihasilkan adalah warna hitam. Nilai value maksimum adalah 1 (100\%), di mana warna yang dihasilkan akan memiliki tingkat kecerahan maksimum. 
Nilai toleransi elemen value akan mempengaruhi tingkat kecerahan warna objek yang ikut terseleksi dalam proses segmentasi warna. Berikut ini merupakan contoh kasus yang akan menunjukkan bagaimana pengaruh toleransi elemen value terhadap hasil segmentasi. Contoh kasus berikut ini terdapat beberapa objek lingkaran dengan nilai hue, saturation yang sama tetapi memiliki nilai value yang berbeda-beda, dengan demikian terlihat pengaruh toleransi value tanpa dipengaruhi elemen warna hue dan saturation.

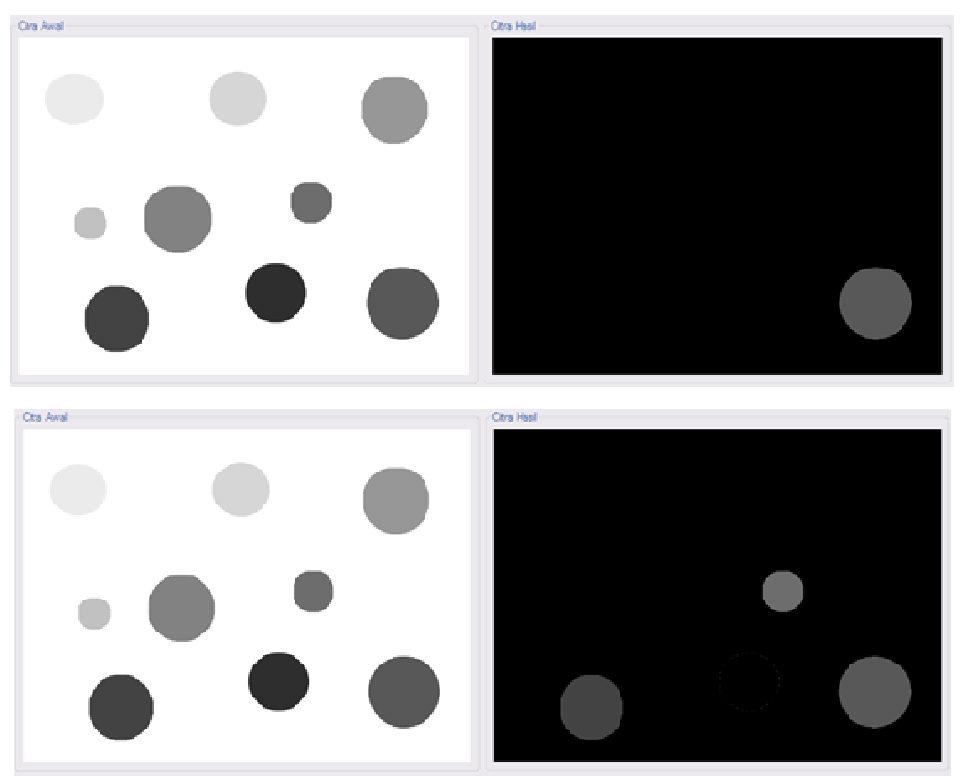

Gambar 6a (atas) dan 6b (bawah). Segmentasi Dengan Toleransi Value

\section{Analisa Proses Deteksi Objek}

Proses segmentasi warna citra akan menghasilkan citra objek tertutup dengan warna tertentu dan berlatarbelakang warna hitam, dengan demikian hasil proses segmentasi akan sangat berpengaruh pada proses analisa objek. Proses analisa objek terbagi menjadi 2 sub proses, yaitu proses perhitungan objek dan proses deteksi objek.

Proses deteksi objek dan pehitungan objek dilakukan dengan menggunakan class BlobCounter yang ada pada pustaka Aforge.net, dengan kondisi filter blob berukuran minimal 5x5 piksel. Berikut ini merupakan contoh kasus pengujian ukuran objek blob yang terdeteksi. 

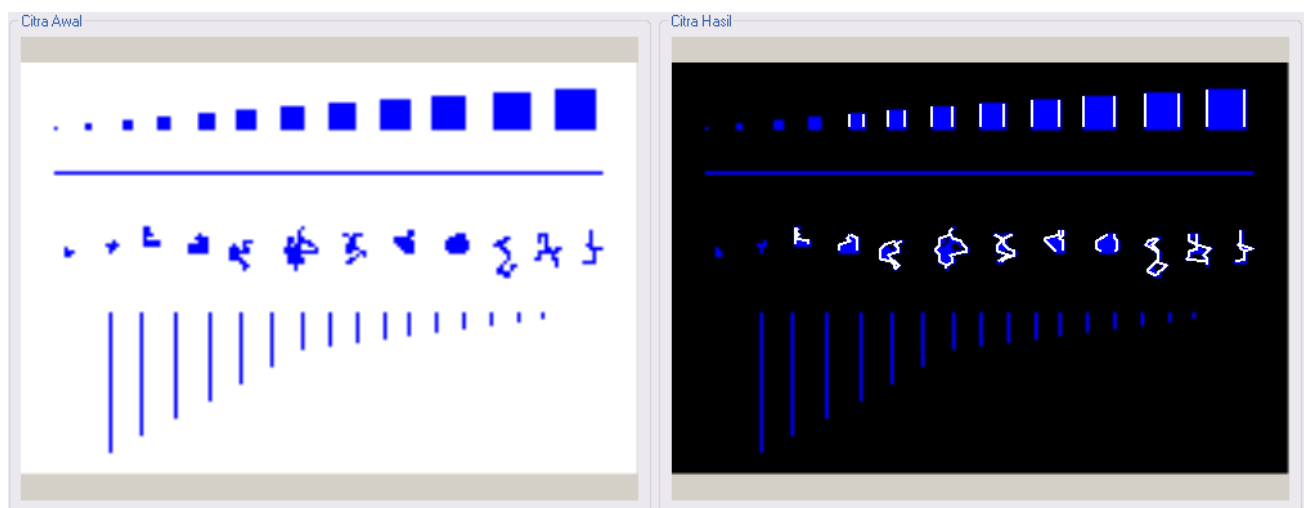

Gambar 7. Deteksi Ukuran Objek Blob

Gambar 7 menunjukkan ukuran blob yang terdeteksi oleh sistem. Pada gambar tersebut sebelah kiri merupakan citra awal yang menjadi input sistem. Baris pertama pada citra awal

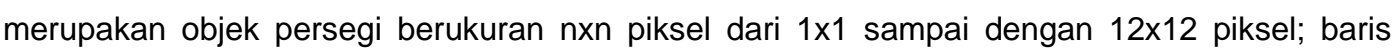
kedua merupakan sebuah garis dengan ukuran 1x159 piksel; baris ketiga merupakan objek dengan berbagai bentuk dan variasi ukuran; baris keempat merupakan kumpulan garis vertikal dengan ukuran 1x40 piksel sampai dengan 1x1 piksel. Bagian sebelah kanan merupakan citra hasil deteksi objek melalui class BlobCounter. Pada citra hasil, objek yang terdeteksi akan terhighlight dengan tepian warna putih. Hasil deteksi objek dapat kita lihat bahwa objek dengan ukuran lebih besar atau sama dengan $5 \times 5$ piksel akan ter-highlight, sebaliknya dengan objek yang berukuran lebih kecil tidak ter-highlight.

Pada suatu citra, di mana terdapat suatu objek memiliki sebuah warna tertentu di dalamnya, warna tersebut terkadang tidak bernilai mutlak akan tetapi dipengaruhi oleh intensitas cahaya yang dipantulkan oleh objek tersebut. Bentuk dan tekstur objek akan mempengaruhi nilai warna pada bagian tertentu sehingga dalam suatu objek pada citra memiliki intensitas warna dan gelap-terang yang berbeda pada bagian tertentu. Proses segmentasi warna dan analisa objek pada objek yang bersangkutan dapat dioptimalkan dengan merubah nilai toleransi pada tiap elemen warna Hue, Saturation dan Value.

\section{Pengujian Area Terdeteksi}

Cahaya memiliki kaitan yang erat dengan warna suatu objek, intensitas cahaya pada suatu bagian objek akan menyebabkan warna pada objek dalam suatu citra berbeda dengan warna pada bagian lain. Area terdeteksi pada satu objek dalam suatu citra dipengaruhi oleh nilai acuan yang dihasilkan dari pengolahan sampel warna dan nilai toleransi warna HSV yang menjadi input. Pada pengujian area deteksi salah satu objek dalam proses analisa objek digunakan citra dengan objek berwarna homogen dan satu sumber cahaya. Ditentukan beberapa titik pada objek dengan tingkat pencahayaan berbeda untuk diambil sebagai sampel warna sehingga dihasilkan suatu nilai acuan warna. Proses pengujian akan menggunakan 
sampel warna yang sama sehingga dihasilkan nilai acuan warna yang konstan. Dengan nilai acuan yang sama kemudian diberikan beberapa nilai toleransi yang berbeda untuk melihat area objek terdeteksi oleh sistem. Nilai toleransi warna yang digunakan antara lain: 0, standar deviasi dari sampel warna, dan 3 nilai empiris (percobaan). Untuk menganalisa area terdeteksi dilakukan 2 pengujian, pengujian I menguji area terdeteksi dengan satu objek, sedangkan pengujian II menguji area terdeteksi dengan beberapa objek pada citra.

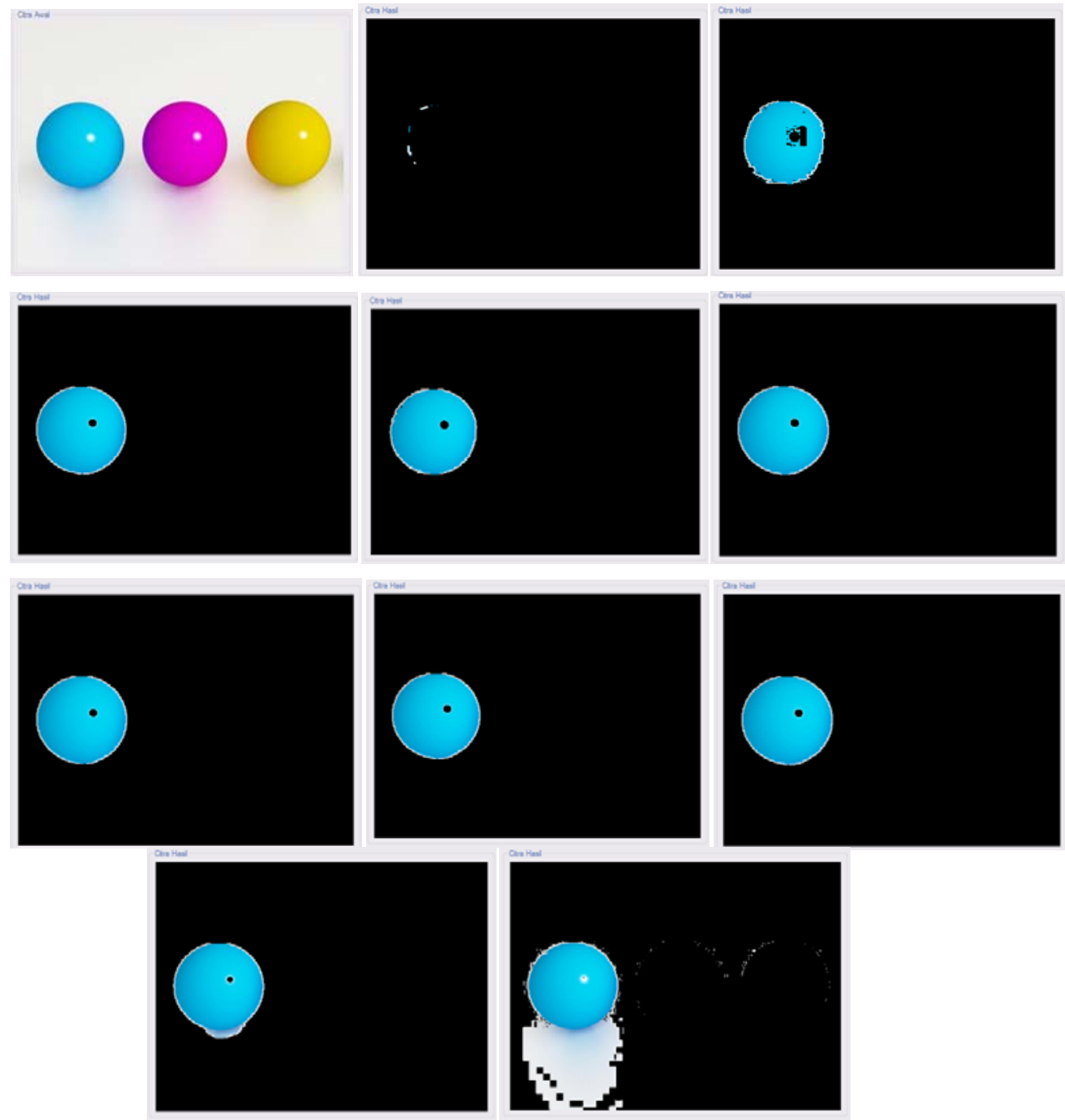

Gambar 8a, 8b, 8c (baris pertama dari kiri ke kanan),

$8 d, 8 e, 8 f$ (baris kedua dari kiri ke kanan),

$8 \mathrm{~g}, 8 \mathrm{~h}, 8 \mathrm{i}$ (baris ketiga dari kiri ke kanan),

8j, 8k (baris keempat dari kiri ke kanan)

\section{Pengujian Area Deteksi Bola}


Pengujian I pada rangkaian gambar 8 dan tabel 1 menggunakan citra bolala.bmp, yang ditunjukkan oleh gambar $8 a$, berukuran $800 \times 600$ piksel. Rangkaian pengujian I akan mencoba mendeteksi salah satu bola berwarna cyan yang berada di bagian kiri citra input(gambar 8a). Objek bola dalam gambar tersebut memiliki diameter 215 piksel dengan demikian luasan total penampang bola yang berbentuk lingkaran sebesar 36320 piksel. Sampel warna yang diambil sebanyak 5 buah antara lain: bagian ujung kiri $\square$ (HSV = 1951 0.74), tengah $\square$ (HSV= 188 $0.960 .96)$, atas $\square(H S V=1920.990 .84)$, sekitar titik putih $\square(H S V=1880.660 .98)$ dan ujung kanan $(H S V=1911$ 0.84). Dari 5 buah sampel warna tersebut dihasilkan nilai acuan warna HSV = 1910.990 .89 dan nilai standar deviasi sebesar hue $3^{\circ}$, saturation 13.18\%, value 8.68\%.

Gambar 8b sampai dengan gambar 8k merupakan hasil pengujian I. Gambar 8b merupakan hasil pengujian pertama dengan nilai toleransi hue $0^{\circ}$, saturation $0 \%$, value 0 . Gambar 8c merupakan hasil pengujian kedua dengan nilai toleransi hasil perhitungan standar deviasi pada setiap elemen dalam sampel warna. Gambar 8d, 8e sampai dengan 8k masingmasing merupakan hasil pengujian ketiga, keempat sampai dengan kesepuluh, yang menggunakan nilai toleransi empiris (hasil coba-coba). Area terdeteksi oleh sistem dapat ditunjukkan dengan area yang memiliki garis tepi berwarna putih. Hasil dari pengujian pada gambar 8 secara detail ditunjukkan pada tabel 1.

Tabel 1

Hasil Pengujian I

\begin{tabular}{|l|l|l|l|l|l|l|l|}
\hline \multirow{2}{*}{ No } & \multirow{2}{*}{ Citra hasil } & \multicolumn{2}{|l|}{ Toleransi } & $\begin{array}{l}\text { Jumlah } \\
\text { objek } \\
\text { terdeteksi }\end{array}$ & $\begin{array}{l}\text { Total area } \\
\text { terdeteksi } \\
\text { (piksel) }\end{array}$ & $\begin{array}{l}\text { Persen area } \\
\text { terdeteksi (\%) }\end{array}$ \\
\cline { 3 - 8 } & & $\mathbf{H}\left(^{\circ}\right)$ & $\mathbf{S}(\%)$ & $\mathbf{V}(\%)$ & 119 & 0.33 \\
\hline $\mathbf{1}$ & $8 \mathrm{~b}$ & 0 & 0 & 0 & 3 & 28119 & 77.42 \\
\hline $\mathbf{2}$ & $8 \mathrm{c}$ & 3 & 13.18 & 8.68 & 2 & 33737 & 92.89 \\
\hline $\mathbf{3}$ & $8 \mathrm{~d}$ & 8 & 33 & 15 & 1 & 34663 & 95.44 \\
\hline $\mathbf{4}$ & $8 \mathrm{e}$ & 14 & 33 & 25 & 1 & 34815 & 95.96 \\
\hline $\mathbf{5}$ & $8 \mathrm{f}$ & 14 & 38 & 25 & 1 & 34938 & 96.19 \\
\hline $\mathbf{6}$ & $8 \mathrm{~g}$ & 14 & 44 & 33 & 1 & 35013 & 96.40 \\
\hline $\mathbf{7}$ & $8 \mathrm{~h}$ & 23 & 44 & 33 & 1 & 35013 & 96.40 \\
\hline $\mathbf{8}$ & $8 \mathrm{i}$ & 33 & 44 & 33 & 1 & 36961 & 101.76 \\
\hline $\mathbf{9}$ & $8 \mathrm{j}$ & 33 & 70 & 33 & 1 & 75518 & 207.92 \\
\hline $\mathbf{1 0}$ & $8 \mathrm{k}$ & 33 & 100 & 33 & 3 & & \\
\hline
\end{tabular}

Berdasarkan rangkaian pengujian I dapat disimpulkan bahwa bagian objek dengan tingkat pencahayaan yang kontras tidak dapat terdeteksi secara sempurna, jika dilakukan penambahan toleransi secara berlebihan untuk mendeteksi area pada bagian objek dengan perbedaan warna yang kontras akan mengakibatkan area yang tidak diinginkan ikut terseleksi, 
seperti pada pengujian no 9 dan 10. Berdasarkan hasil pengujian I dengan beberapa nilai toleransi yang berbeda, diperoleh nilai toleransi optimal untuk hue $14^{\circ}$, saturation $44 \%$ dan value $33 \%$. Penambahan toleransi melebihi nilai tersebut tidak memberikan peningkatan hasil area terdeteksi yang cukup signifikan.

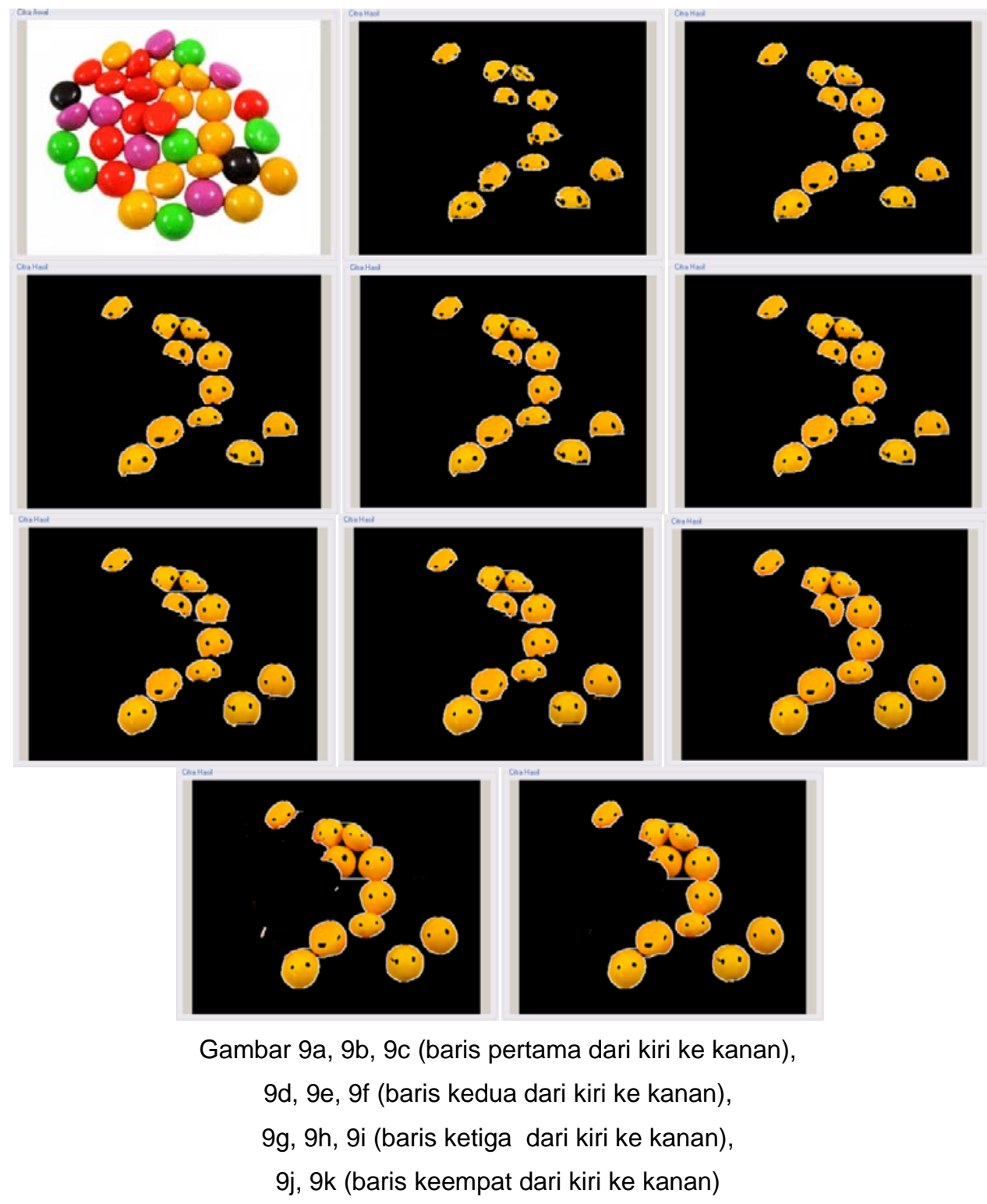

Pengujian Area Deteksi Permen

Pengujian II, pada rangkaian gambar 9 dan tabel 2, menganalisa jumlah objek dan area terdeteksi beberapa objek permen berwarna kuning pada citra permen.jpg berukuran 506×405 piksel. Citra yang akan menjadi input ditunjukkan oleh gambar 9a. Pada citra awal (gambar 9a) secara visual dapat diketahui jumlah objek permen berwarna kuning berjumlah 11 
buah. Sampel warna yang diambil sebanyak 5 buah, masing-masing diambil dari beberapa bagian permen kuning yang dianggap merepresentasikan perubahan warna akibat pengaruh cahaya, yaitu: (HSV=45 0.86 1), (HSV=43 0.990 .98$), \quad$ (HSV=35 0.990 .82 ),

(HSV=38 10.87$), \square(H S V=450.740 .99)$. Dari 5 buah sampel warna tersebut dihasilkan nilai acuan warna HSV $=430,990,98$ dan nilai standar deviasi, besar masing-masing elemen warna antara lain: hue $4^{\circ}$, saturation $10.21 \%$, value $7.30 \%$.

Rangkaian gambar 9b sampai dengan 9k merupakan hasil pengujian II. Gambar 9b merupakan hasil pengujian kedua dengan nilai toleransi hasil perhitungan standar deviasi pada setiap elemen dalam sampel warna. Gambar 9c, 9d sampai dengan 9k masing-masing merupakan hasil pengujian ketiga, keempat sampai dengan kesepuluh, yang menggunakan nilai toleransi empiris (hasil coba-coba). Area terdeteksi oleh sistem dapat ditunjukkan dengan area yang memiliki garis tepi berwarna putih. Hasil dari pengujian pada gambar 9 secara detail ditunjukkan pada Tabel 2.

Tabel 2. Hasil Pengujian II

\begin{tabular}{|c|c|c|c|c|c|c|}
\hline \multirow{2}{*}{ No } & \multirow{2}{*}{$\begin{array}{c}\text { Citra } \\
\text { Hasil }\end{array}$} & \multicolumn{3}{|c|}{ Toleransi } & $\begin{array}{c}\text { Jumlah } \\
\text { objek } \\
\text { terdeteksi }\end{array}$ & $\begin{array}{c}\text { Total area } \\
\text { terdeteks } \\
\text { (piksel) }\end{array}$ \\
\cline { 3 - 6 } & $\mathbf{H ~ ( { } ^ { \circ } \text { ) }}$ & $\mathbf{S ~ ( \% )}$ & $\mathbf{V ~ ( \% )}$ & 13704 \\
\hline $\mathbf{1}$ & $9 \mathrm{~b}$ & 4 & 10.21 & 7.30 & 11 & 18235 \\
\hline $\mathbf{2}$ & $9 \mathrm{c}$ & 10 & 10.21 & 7.30 & 11 & 19456 \\
\hline $\mathbf{3}$ & $9 \mathrm{~d}$ & 10 & 10.21 & 10 & 10 & 19717 \\
\hline $\mathbf{4}$ & $9 \mathrm{e}$ & 10 & 15 & 10 & 10 & 19881 \\
\hline $\mathbf{5}$ & $9 \mathrm{f}$ & 10 & 20 & 10 & 10 & 23303 \\
\hline $\mathbf{6}$ & $9 \mathrm{~g}$ & 10 & 20 & 25 & 10 & 24125 \\
\hline $\mathbf{7}$ & $9 \mathrm{~h}$ & 10 & 20 & 40 & 10 & 27574 \\
\hline $\mathbf{8}$ & $9 \mathrm{i}$ & 20 & 20 & 40 & 6 & 28421 \\
\hline $\mathbf{9}$ & $9 \mathrm{j}$ & 30 & 20 & 40 & 7 & 27813 \\
\hline $\mathbf{1 0}$ & $9 \mathrm{k}$ & 25 & 20 & 35 & 5 & \\
\hline
\end{tabular}

Rangkaian pengujian II menunjukan bahwa objek yang bersingungan dengan objek berwarna serupa akan terdeteksi dalam 1 area objek. Perhitungan objek yang terdeteksi berdasarkan area objek yang terpisahkan oleh warna diluar jangkauan nilai toleransi. Pada hasil rangkaian pengujian II menunjukkan bahwa pencahayaan yang menghasilkan efek warna lain (dalam hal ini dapat dilihat bahwa bagian tepi permen warna kuning yang menjadi objek analisa berwarna kemerahan) dapat diatasi dengan menambahkan toleransi hue. Nilai toleransi yang dinilai optimal untuk mendeteksi objek permen berwarna kuning pada citra 9a adalah sebesar: hue $25^{\circ}$, saturation $40 \%$, value $35 \%$ karena pada nilai toleransi tersebut ,bentuk setiap butir permen mencapai secara visual mendekati bentuk pada citra awal (gambar 9a). Nilai toleransi tersebut akan optimal dengan syarat nilai warna acuan yang dihasilkan dari sampel warna bernilai HSV $=430,990,98$. 


\section{Kesimpulan}

Segmentasi warna berdasarkan deteksi warna HSV merupakan proses segmentasi terkontrol dengan filter warna HSV. Filter warna HSV akan memisahkan warna tertentu sesuai dengan warna acuan dan nilai toleransi tiap elemen warna HSV. Kontrol pengguna melalui sampel warna dan toleransi warna yang menjadi acuan filter sehingga dapat diperoleh segmen dengan warna yang sesuai. Hasil segmentasi warna berdasarkan deteksi warna HSV sangat dipengaruhi oleh sampel warna dan nilai toleransi warna yang menjadi acuan proses segmentasi. Pencahayaan, letak, tekstur dan kontur benda atau latar belakang citra akan sangat mempengaruhi hasil segmentasi dan deteksi objek.

\section{Daftar Pustaka}

[1] Castleman K.R. (1996). Digital image processing. Prentice Hall, New Jersey.

[2] Forsyth, D.A., Ponce, J. (2003). Computer vision: A modern approach. Prentice Hall, New Jersey.

[3] Giannakopoulos, T. (2008). Matlab color detection software, Department of Informatics and Telecommunications, University of Athens, Greece. Diambil dari http://www.di.uoa.gr/ tyiannak

[4] Gonzalez, Rafael C., Woods, Richard E. (2001). Digital image processing. Prentice Hall, New Jersey.

[5] Gunanto, S.G. (2009). Segmentasi warna bagian tubuh manusia pada citra 2D. Proceeding SENTIA.

[6] Perales, F. (2002). Human motion analysis \& synthesis using computer vision and graphics techniques, State of Art and Applications, Report on Computer Graphics and Vision Group, Department of Computer Science-Universitat deles Illes Balears (UIB), Perancis

[7] Rujikietgumjorn, S. (2008). Segmentation methods for multiple body parts, Project in lieu of Thesis, University of Tennessee, Knoxville. 